\title{
Pengaruh Pendapatan Asli Daerah (PAD), Dana Alokasi Umum (DAU), dan Dana Alokasi Khusus (DAK) terhadap Belanja Modal dengan Pendapatan Per Kapita sebagai Variabel Pemoderasi \\ (Studi Kasus Pada Pemerintahan Kabupaten dan Kota di Jawa Tengah Periode Tahun 2013 - 2017)
}

\author{
IKA SURYATININGRUM \\ IIN INDARTI \\ WENNY ANA ADNANTI
}

\author{
Sekolah Tinggi Ilmu Ekonomi Widya Manggala \\ Jalan Sriwijaya No. 32 \& 36 Semarang 50242 \\ Email : ikasuryatiningrum97@gmail.com
}

Diterima 11 September 2020; disetujui 21 September 2020;

\begin{abstract}
Regional autonomy and fiscal decentralization give local governments the authority to explore revenue and perform the role of allocation independently in setting development priorities in which there is a component of capital expenditure. This research aimed to examine and analyze the effect of Own Source Revenue, General Allocation Fund, and Special Allocation Fund on Capital Expenditure that are moderated by Percapita Income in Regency/City Governments in Central Java Province. The population of this research were the Regency / City Governments in Central Java which consists of 29 Regencies and 6 Cities in 2013 - 2017. The sampling technique used was saturated sampling. The secondary data was collected from APBD Realization Reports and Per Capita GRDP Tables in 2013-2017. The data analysis technique used were Multiple Regression Analysis and Moderated Regression Analysis (MRA). The results showed that Own Source Revenue, General Allocation Fund and Special Allocation Fund, both partially and simultaneously had a significant positive effect on Capital Expenditure. Per Capita Income as a moderating variable can strengthen the effect of Own Source Revenue on Capital Expenditure, but it cannot strengthen the effect of General Allocation Fund and Special Allocation Fund on Capital Expenditure.
\end{abstract}

Keywords : Own Source Revenue, General Allocation Fund, Special Allocation Fund, Percapita Income, Capital Expenditure.

\section{PENDAHULUAN}

Latar Belakang. Otonomi daerah yang dilaksanakan per 1 Januari 2001 telah mem- berikan peran yang lebih besar kepada pemerintah dan pelaku ekonomi daerah (Waluyo, 2007 dalam Badrudin, 2017:3). Melalui otonomi daerah dan desentralisasi 
fiskal, pemerintah daerah memiliki wewenang untuk menggali pendapatan dan melakukan peran alokasi secara mandiri dalam menetapkan prioritas pembangunan (Badrudin, 2017). Dalam berbagai penelitian, desentralisasi fiskal diproksi dengan rasio pada komponen pendapatan daerah dan pengeluaran daerah pada APBD (Sasana, 2009 dan Mursinto, 2004). Pendapatan daerah pada APBD meliputi PAD, dana perimbangan dan lain-lain pendapatan. Pengeluaran daerah meliputi belanja rutin (Aparatur Daerah) dan belanja pembangunan (Belanja Publik). Dalam belanja pembangunan terdapat komponen belanja modal. Oleh karena itu apabila pemerintah daerah ingin meningkatkan kesejahteraan masyarakat maka pemerintah daerah harus meningkatkan anggaran belanja pembangunan termasuk belanja modal (Badrudin, 2017). Dalam meningkatkan anggaran belanja pembangunan yang didalamnya terdapat komponen belanja modal maka pemerintah daerah harus mampu meningkatkan pendapatan daerah melalui peningkatan PAD, dana perimbangan, dan lain-lain pendapatan (Badrudin, 2017).

Pelaksanaan desentralisasi fiskal akan berjalan baik apabila pemerintah pusat mampu melakukan pengawasan dan enforcement, serta terdapat keseimbangan antara akuntabilitas dan kewenangan dalam pungu- tan pajak dan retribusi daerah sehingga akan mengurangi ketergantungan pemerintah kabupaten/kota terhadap pemerintah pusat seperti pada masa Orde Baru (Badrudin, 2017). Namun, kondisi yang diharapkan ternyata berbanding terbalik dengan Kenyataan dikarenakan daerah menjadi ketergantungan terhadap dana transfer dari pemerintah pusat. Berdasarkan realisasi belanja pemerintah daerah, kualitas belanja daerah masih kurang bagus. Sehing-ga untuk setiap kebutuhan pembangunan penting lainnya termasuk untuk belanja modal yang akhirnya pemerintah daerah menggantungkan kembali pembiayaan APBD pada transfer dari pusat (Sumber : www.news.detik.com).

Menurut catatan Kemenkeu, belanja daerah masih kurang fokus menuntaskan program prioritas karena pemda terlalu banyak mengganggarkan belanja untuk banyak program sehingga tidak memiliki fokus pada setiap tahun anggarannya. Belanja pegawai juga terus naik terutama di Jawa. Pada satu sisi, belanja modal terus menurun akibat gagal lelang dan permasalahan lahan. Sebagian belanja modal juga digunakan untuk membangun gedung dan membeli kendaraan dinas sehingga banyak daerah masih kurang belum mampu mengejar ketertinggalannya dalam pembangunan (Sumber: www.ekonomi.bisnis.com).

\section{Gambar 1}

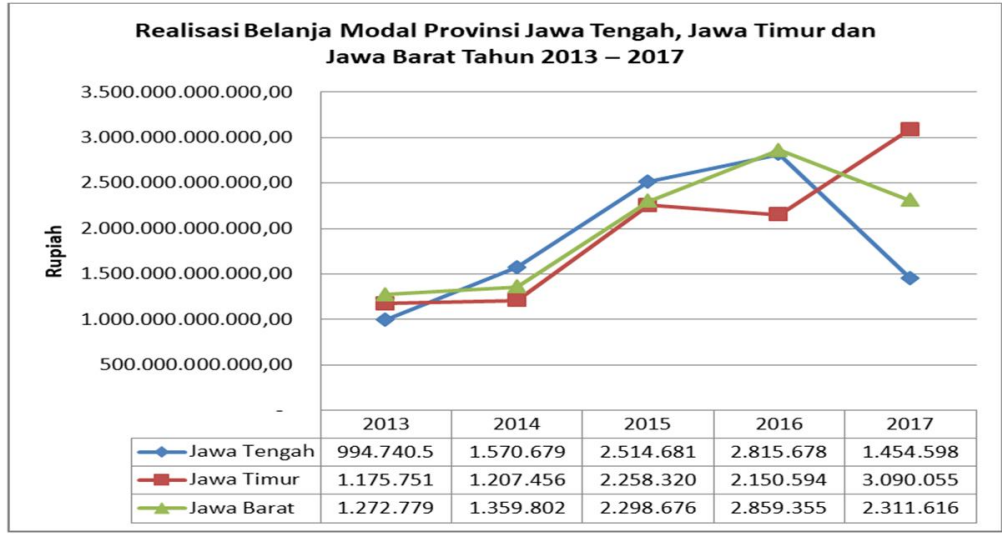

Sumber : http://www.djpk.kemenkeu.go.id 
Berdasarkan data Realisasi APBD Pemerintah Daerah yang dipublikasikan oleh Direktorat Jenderal Perimbangan Keuangan melalui situs www.djpk.kemenkeu.go.id dapat diketahui bahwa Realisasi Belanja Modal Provinsi Jawa Tengah, Jawa Timur dan Jawa Barat periode 2013-2017 yang disajikan dalam grafik 1 tersebut pada masing-masing Provinsi mengalami fluktuatif. Pada Provinsi Jawa Tengah realisasi belanja modal dari tahun 2013 sampai dengan 2016 mengalami kenaikan dan dari tahun 2016 ke tahun 2017 mengalami penurunan. Dengan melihat hasil penurunan Belanja Modal di Jawa Tengah dari tahun 2016 ke tahun 2017 merupakan penurunan yang paling signifikan dibanding dengan provinsi-provinsi Jawa lainnya.

Belanja modal berpengaruh penting terhadap pertumbuhan ekonomi karena akan menggerakkan roda perekonomian daerah. Pengalokasian belanja modal yang lebih tinggi seharusnya bisa dilakukan oleh pemerintah daerah dibandingkan dengan belanja rutin yang kurang bermanfaat (Sari \& Wirama, 2018).

PAD yang merupakan pendapatan daerah bersumber dari hasil pajak daerah, hasil retribusi daerah, hasil pengelolaan kekayaan daerah yang dipisahkan, dan lainlain pendapatan asli daerah yang sah, yang bertujuan untuk memberikan keleluasaan kepada daerah dalam menggali pendanaan dalam pelaksanaan otonomi daerah sebagai perwujudan asas desentralisasi (Badrudin, 2017). Berdasarkan penelitian yang dilakukan oleh Sari \& Wirama (2018) menghasilkan bahwa PAD berpengaruh positif pada alokasi belanja modal. Hal ini didukung oleh penelitian Jaeni \& Anggana (2016) bahwa PAD berpengaruh terhadap belanja modal, begitupun dengan penelitian Aditiya \& Dirgantari (2017) menunjukkan bahwa Pendapatan Asli Daerah (PAD) ber- pengaruh positif signifikan terhadap belanja modal. Akan tetapi adapun penelitian yang tidak sejalan yaitu penelitian Wandira (2013) hasilnya tidak terdapat pengaruh signifikan antara variabel Pendapatan Asli Daerah (PAD) terhadap belanja modal.

DAU merupakan dana yang dialokasikan dalam APBN kepada daerah dengan tujuan pemerataan kemampuan keuangan mendanai kebutuhan antar daerah untuk daerah dalam rangka pelaksanaan desentralisasi (Badrudin, 2017). Berdasarkan penelitian yang dilakukan oleh Sari \& Wirama (2018) menghasilkan bahwa DAU tidak berpengaruh positif pada alokasi belanja modal. Hal tersebut berbeda dengan penelitian Kosim (2017) yang menginformasikan hasil analisis bahwa Dana Alokasi Umum berpengaruh terhadap Belanja Modal. Namun terdapat juga penelitian dari Wibisono \& Wildaniati (2016) yang menghasilkan bahwa Dana Alokasi Umum (DAU) tidak berpengaruh positif terhadap alokasi Anggaran Belanja Modal.

DAK merupakan dana yang dialokasikan kepada Daerah tertentu untuk mendanai kegiatan khusus yang merupakan urusan Daerah (UU 33 Tahun 2004). DAK terdiri dari DAK Fisik dan DAK Non Fisik (Badrudin, 2017). Berdasarkan hasil penelitian Sari \& Wirama (2018) menunjukkan bahwa Dana Alokasi Khusus (DAK) berpengaruh positif terhadap belanja modal. Penelitian tersebut sejalan dengan hasil penelitian Mohklas dan Purwati (2019) bahwa Dana Alokasi Khusus mempunyai pengaruh yang positif dan signifikan terhadap Belanja Modal. Namun terdapat juga hasil penelitian yang tidak sejalan yaitu penelitian Fahrunisah \& Badjuri (2017) hasil Dana Alokasi Khusus (DAK) tidak berpengaruh terhadap belanja modal.

Dengan beragamnya hasil penelitian yang dilakukan sebelumnya kemungkinan 
dapat disebabkan oleh adanya variabel pemoderasi dimana pengaruh tersebut dapat bersifat positif maupun negatif (memperkuat atau memperlemah). Penelitian ini mengacu pada penelitian terdahulu yang dilakukan oleh (Sari \& Wirama, 2018) yang meneliti tentang Pengaruh PAD, DAU, dan DAK Pada Alokasi Belanja Modal dengan pendapatan per kapita sebagai pemoderasi. Perbedaan penelitian tersebut dengan penelitian ini adalah terletak pada objek dan sampel yang digunakan.

Pendapatan per kapita ini digunakan sebagai variabel pemoderasi karena diduga mampu untuk memperkuat PAD pada alokasi belanja modal (Sari \& Wirama, 2018). Apabila peningkatan PAD dapat mendorong pertumbuhan ekonomi daerah, maka terdapat kemungkinan pendapatan per kapita memperkuat pengaruh DAU dan DAK pada belanja modal (Sari \& Wirama, 2018).

Maka berdasarkan latar belakang tersebut penulis tertarik untuk mengadakan penelitian lebih lanjut mengenai "Pengaruh Pendapatan Asli Daerah (PAD), Dana Alokasi Umum (DAU), dan Dana Alokasi Khusus (DAK) Terhadap Belanja Modal dengan Pendapatan Per Kapita Sebagai Variabel Pemoderasi Pada Pemerintahan Kabupaten/Kota di Jawa Tengah Periode Tahun 2013 - 2017' .

Tujuan Penelitian. Tujuan dari penelitian ini adalah untuk menganalisis seberapa besar pengaruh PAD, DAU, dan DAK terhadap Belanja Modal dengan Pendapatan per Kapita sebagai variabel pemoderasi di Kabupaten/Kota Provinsi Jawa Tengah Periode Tahun 2013 - 2017.

\section{TINJAUAN PUSTAKA}

Teori Kontinjensi. Teori kontinjensi yang deskriptif membahas tentang mengapa pemimpin berperilaku berbeda antara satu situasi dengan situasi lainnya, sementara teori kontinjensi yang preskriptif membahas perilaku yang paling efektif dalam setiap jenis situasi (Yukl, 2010 dalam Sugiarthi dan Supadmi, 2014). Penelitian yang menggunakan pendekatan kontinjensi dilakukan dengan tujuan mengidentifikasi berbagai variabel kontinjensi yang memengaruhi perancangan. Hakikat teori kontinjensi adalah tidak ada satu cara terbaik yang bisa digunakan dalam semua keadaan (situasi) lingkungan (Mulyani dan Wibowo, 2017). Pendekatan kontinjensi juga diterapkan dalam akuntansi sektor publik. Faktor kontinjensi yang digunakan pada penelitian ini adalah pendapatan per kapita (Sari dan Wirama, 2018).

Belanja Modal. Menurut Peraturan Pemerintah No 71 Tahun 2010 tentang Standar Akuntansi Pemerintahan, belanja modal adalah pengeluaran anggaran untuk perolehan asset tetap dan aset lainnya yang memberi manfaat lebih dari satu periode akuntansi. Belanja modal meliputi antara lain belanja modal untuk perolehan tanah, gedung dan bangunan, peralatan, aset tak berwujud. Belanja modal menampung seluruh pengeluaran negara yang dialokasikan untuk pembelian barang-barang kebutuhan investasi (dalam bentuk asset tetap dan asset lainnya) (Bastian, 2006). Belanja modal dapat dikategorikan dalam lima kategori utama yaitu belanja modal tanah, belanja modal peralatan dan mesin, belanja modal gedung dan bangunan, belanja modal jalan, irigasi, dan jaringan, serta belanja modal fisik lainnya (Halim, 2007 dalam Badrudin, 2017).

Pendapatan Asli Daerah. PAD dalam UU Nomor 33 Tahun 2004 adalah pendapatan yang diperoleh Daerah yang dipungut berdasarkan Peraturan Daerah sesuai dengan peraturan perundang-undangan. PAD pada 
kelompok pendapatan daerah merupakan jenis pendapatan yang terdiri atas pajak daerah, retribusi daerah, hasil pengelolaan kekayaan daerah yang dipisahkan, dan lainlain pendapatan asli daerah yang sah. PAD bertujuan memberikan kewenangan kepada Pemerintah Daerah untuk mendanai pelaksanaan otonomi daerah sesuai dengan potensi daerah sebagai perwujudan desentralisasi. Dalam upaya meningkatkan PAD, daerah dilarang menetapkan peraturan daerah tentang pendapatan yang menyebabkan ekonomi biaya tinggi dan dilarang menetapkan peraturan daerah tentang pendapatan yang menghambat mobilitas penduduk, lalu lintas barang dan jasa antardaerah, dan kegiatan impor/ekspor (UU Nomor 33 Tahun 2004).

Dana Alokasi Umum. Berdasarkan UU Nomor 33 Tahun 2004 Dana Alokasi Umum, selanjutnya disebut DAU adalah dana yang bersumber dari pendapatan APBN yang dialokasikan dengan tujuan pemerataan kemampuan keuangan antardaerah untuk mendanai kebutuhan daerah dalam rangka pelaksanaan desentralisasi. DAU untuk suatu daerah dialokasikan atas dasar celah fiskal dan alokasi dasar. Celah fiskal adalah kebutuhan fiskal dikurangi dengan kapasitas fiskal daerah. kebutuhan fiskal daerah merupakan kebutuhan pendanaan daerah untuk melaksanakan fungsi layanan dasar umum. Setiap kebutuhan pendanaan sebagaimana diukur secara berturut-turut dengan jumlah penduduk, luas wilayah, indeks kemahalan konstruksi, produk domestik regional bruto per kapita, dan indeks pembangunan manusia. Kapasitas fiskal daerah merupakan sumber pendanaan daerah yang berasal dari PAD dan dana bagi hasil. Sedangkan alokasi dasar dihitung berdasarkan jumlah gaji Pegawai Negeri Sipil Daerah. Alokasi DAU bagi daerah yang potensi fiskalnya besar tetapi kebutuhan fiskal kecil akan memperolah alokasi DAU relatif kecil. Sebaliknya, daerah yang potensi fiskalnya kecil, namun kebutuhan fiskal besar akan memperoleh alokasi DAU relative besar. Secara implisit, prinsip tersebut menegaskan fungsi DAU sebagai faktor pemerataan kapasistas fiskal (Badrudin, 2017).

Dana Alokasi Khusus. Berdasarkan UU Nomor 33 Tahun 2004 Dana Alokasi Khusus, selanjutnya disebut DAK, adalah dana yang bersumber dari pendapatan APBN yang dialokasikan kepada Daerah tertentu dengan tujuan untuk membantu mendanai kegiatan khusus yang merupakan urusan Daerah dan sesuai dengan prioritas nasional. Besaran DAK ditetapkan setiap tahun dalam APBN. Pemerintah menetapkan kriteria DAK yang meliputi kriteria umum, kriteria khusus, dan kriteria teknis. Menurut Peraturan Menteri Keuangan Nomor 50/ PMK.70/2017 tentang pengelolaan transfer ke daerah dan dana desa, dana transfer khusus adalah dana yang dialokasikan dalam Anggaran Pendapatan dan Belanja Negara kepada daerah dengan tujuan untuk membantu mendanai kegiatan khusus, baik fisik maupun nonfisik yang merupakan urusan daerah. DAK Fisik dimanfaatkan dalam bentuk DAK Reguler, DAK Infrastruktur Publik Daerah, dan DAK Afirmasi. DAK non fisik lebih ditujukkan untuk pendanaan BOS, PAUD, Tambahan Gaji Pengajar PNSD, Tunjangan Guru serta pembangunan daerah (Badrudin, 2017).

Pendapatan Per Kapita. Pertumbuhan ekonomi daerah akan merangsang meningkatnya pendapatan penduduk di daerah yang bersangkutan, seiring dengan meningkatnya pendapatan penduduk akan berdampak pada meningkatnya pendapatan per Kapita (Harianto dan Adi, 2007). Pertumbuhan ekonomi suatu daerah yang meningkat berdampak pada peningkatan pendapatan 
per kapita penduduk, sehingga tingkat konsumsi dan produktivitas penduduk semakin meningkat (Adyatama dan Oktaviani, 2015). Pendapatan per kapita ini digunakan sebagai variabel pemoderasi karena diduga mampu untuk memperkuat PAD pada alokasi belanja modal (Sari dan Wirama, 2018). Pendapatan per kapita yang meningkat merupakan salah satu tanda bahwa ratarata kesejahteraan penduduk telah meningkat. Nilai PDRB dibagi jumlah penduduk diwilayah tersebut menghasilkan pendapatan per kapita. Pertumbuhan pendapatan per kapita yang positif dari tahun ke tahun menjadi indikator laju pertumbuhan ekonomi, dimana peningkatan pendapatan akan meningkatkan taraf kesejahteraan dan kemampuan masyarakat untuk memenuhi kebutuhannya. Peningkatan aktivitas perekonomian akan memberikan sumbangan kepada pendapatan daerah dalam bentuk setoran pajak yang akan digunakan daerah untuk membiayai pembangunan sarana prasarana umum dan melaksanakan pelayanan kepada masyarakat. (Dengah dkk, 2014).

Penelitian Terdahulu. Penelitian terhadap belanja modal sudah banyak dilakukan, ringkasan mengenai beberapa penelitian terdahulu dapat dilihat pada tabel 1 .

Hipotesis. Berdasarkan landasan teori dan penelitian terdahulu, maka hipotesis yang diajukan dalam penelitian ini adalah sbb:

$\mathrm{H}_{1}$ : Pendapatan Asli Daerah berpengaruh positif terhadap belanja modal pada Pemerintahan Kabupaten dan Kota di Jawa Tengah Periode Tahun 2013-2017.

$\mathrm{H}_{2}$ : Dana Alokasi Umum berpengaruh positif terhadap belanja modal pada Pemerintahan Kabupaten dan Kota di Jawa Tengah Periode Tahun 2013-2017.

$\mathrm{H}_{3}$ : Dana Alokasi Khusus berpengaruh positif terhadap belanja modal pada
Pemerintahan Kabupaten dan Kota di Jawa Tengah Periode Tahun 2013-2017. $\mathrm{H}_{4}$ : Pendapatan per Kapita mempengaruhi hubungan antara Pendapatan Asli Daerah dan belanja modal pada Pemerintahan Kabupaten dan Kota di Jawa Tengah Periode Tahun 2013-2017. $\mathrm{H}_{5}$ : Pendapatan per kapita mempengaruhi hubungan antara Dana Alokasi Umum dan belanja modal pada Pemerintahan Kabupaten dan Kota di Jawa Tengah Periode Tahun 2013-2017.

$\mathrm{H}_{6}$ : Pendapatan per kapita mempengaruhi hubungan antara Dana Alokasi Khusus dan belanja modal pada Pemerintahan Kabupaten dan Kota di Jawa Tengah periode tahun 2013-2017.

\section{METODE PENELITIAN}

Jenis Penelitian. Jenis penelitian yang digunakan penulis dalam penelitian ini adalah penelitian kausal komparatif (causalcomparative Research) yang merupakan tipe penelitian dengan karak-teristik masalah berupa hubungan sebab-akibat antara dua variabel atau lebih (Indriantoro dan Supomo, 2002).

Definisi Operasional. Berikut ini definisi operasional dari masing-masing variabel yang digunakan dalam penelitian:

\section{Belanja Modal (Y)}

Belanja modal adalah pengeluaran anggaran untuk perolehan asset tetap dan aset lainnya yang memberi manfaat lebih dari satu periode akuntansi. Belanja modal meliputi antara lain belanja modal untuk perolehan tanah, gedung dan bangunan, peralatan, aset tak berwujud (PP No. 71 Tahun 2010). Dimensi dan indikator dari belanja modal dalam penelitian ini adalah belanja tanah; belanja peralatan dan mesin; belanja gedung dan bangunan ; 


\section{Tabel 1}

\section{Ringkasan Penelitian Terdahulu}

\begin{tabular}{|c|c|c|c|}
\hline No & Nama (Tahun) & Variabel & Hasil Penelitian \\
\hline 1 & $\begin{array}{l}\text { Mohklas dan } \\
\text { Purwati (2019) }\end{array}$ & $\begin{array}{l}\text { - Pendapatan Asli Daerah (PAD) } \\
\text { - Dana Alokasi Umum (DAU) } \\
\text { - Dana Alokasi Khusus (DAK) } \\
\text { - Belanja Modal (BM) } \\
\text { - Pertumbuhan Ekonomi (PE) }\end{array}$ & $\begin{array}{l}\text { PAD, DAU dan DAK berpengaruh positif } \\
\text { dan signifikan terhadap belanja modal. PE } \\
\text { tidak memoderasi hubungan antara PAD, } \\
\text { DAU namun dapat memoderasi DAK dengan } \\
\text { BM. }\end{array}$ \\
\hline 2 & Cahyaning (2018) & $\begin{array}{l}\text { - Pendapatan Asli Daerah } \\
\text { - DAU } \\
\text { - DBH } \\
\text { - Belanja Modal } \\
\text { - Pertumbuhan Ekonomi }\end{array}$ & $\begin{array}{l}\text { - Pendapatan Asli Daerah, Dana Alokasi } \\
\text { Umum berpengaruh pada belanja modal. } \\
\text { - } \quad \text { Dana Bagi Hasil tidak berpengaruh pada } \\
\text { belanja modal. } \\
\text { - } \quad \text { Pertumbuhan ekonomi mampu } \\
\text { memoderasi variabel Dana Bagi Hasil, } \\
\text { namun tidak mampu memoderasi } \\
\text { Pendapatan Asli Daerah dan Dana Alokasi } \\
\text { Umum pada belanja modal. }\end{array}$ \\
\hline 3 & $\begin{array}{l}\text { Jaeni dan } \\
\text { Anggana } \\
(2016)\end{array}$ & $\begin{array}{l}\text { - PAD } \\
\text { - Bantuan Propinsi } \\
\text { - Belanja Modal } \\
\text { - Pertumbuhan Ekonomi }\end{array}$ & $\begin{array}{l}\text { - PAD, Bantuan Propinsi dan Pertumbuhan } \\
\text { Ekonomi berpengaruh terhadap Belanja } \\
\text { Modal. } \\
\text { - } \text { Pertumbuhan Ekonomi terbukti } \\
\text { memoderasi PAD terhadap Belanja Modal. }\end{array}$ \\
\hline 4 & $\begin{array}{l}\text { Sugiarthi dan } \\
\text { Supadmi (2014) }\end{array}$ & $\begin{array}{l}\text { - PAD } \\
\text { - DAU } \\
\text { - SiLPA } \\
\text { - Belanja Modal } \\
\text { - Pertumbuhan Ekonomi }\end{array}$ & $\begin{array}{l}\text { - PAD, DAU, dan SiLPA berpengaruh } \\
\text { positif dan signifikan pada belanja modal. } \\
\text { - } \text { Variabel moderasi (pertumbuhan ekonomi) } \\
\text { mampu memoderasi variabel PAD dan } \\
\text { DAU, namun tidak mampu memoderasi } \\
\text { variabel SiLPA pada belanja modal }\end{array}$ \\
\hline 5 & $\begin{array}{l}\text { Jaya dan } \\
\text { Dwirandra (2014) }\end{array}$ & $\begin{array}{l}\text { - Pendapatan Asli Daerah } \\
\text { - Belanja Modal } \\
\text { - Pertumbuhan Ekonomi }\end{array}$ & $\begin{array}{l}\text { - Pendapatan asli daerah berpengaruh positif } \\
\text { dan signifikan pada belanja modal. } \\
\text { - } \text { Pertumbuhan ekonomi tidak berpengaruh } \\
\text { signifikan pada belanja modal, tetapi } \\
\text { berpengaruh signifikan dan mampu } \\
\text { memoderasi pengaruh pendapatan asli } \\
\text { daerah pada belanja modal. }\end{array}$ \\
\hline
\end{tabular}

belanja jalan, irigasi dan jaringan; belanja aset tetap lainnya; belanja aset lainnya.

\section{Pendapatan Asli Daerah $\left(X_{1}\right)$}

Pendapatan Asli Daerah adalah pendapatan yang diperoleh daerah yang dipungut berdasarkan Peraturan Daerah sesuai dengan peraturan perundang-undangan. Pendapatan Asli Daerah dalam kelompok pendapatan daerah merupakan jenis pendapatan yang terdiri atas pajak daerah, retribusi daerah, hasil pengelolaan kekayaan daerah yang dipisahkan, dan lain-lain pendapatan asli daerah yang sah (UU No. 33 Tahun 2004). Dimensi dan indikator dari pendapatan asli daerah dalam penelitian ini adalah pajak daerah, retribusi daerah, hasil pengelolaan kekayaan daerah yang dipisahkan, lain - lain Pendapatan Asli Daerah yang sah.

\section{Dana Alokasi Umum $\left(\mathbf{X}_{2}\right)$}

Dana Alokasi Umum adalah dana yang bersumber dari pendapatan APBN yang dialokasikan dengan tujuan pemerataan 
kemampuan keuangan antar-daerah untuk mendanai kebutuhan daerah dalam rangka pelaksanaan desentralisasi. DAU untuk suatu daerah dialokasikan atas dasar celah fiskal dan alokasi dasar (UU No. 33 Tahun 2004). Dimensi dan indikator dari Dana Alokasi Umum dalam penelitian ini adalah alokasi dasar dan celah fiskal.

\section{Dana Alokasi Khusus $\left(X_{3}\right)$}

Dana Transfer Khusus adalah dana yang dialokasikan dalam Anggaran Pendapatan dan Belanja Negara kepada daerah dengan tujuan untuk membantu mendanai kegiatan khusus, baik fisik maupun nonfisik yang merupakan urusan daerah. Dana alokasi Khusus dikelompokkan menjadi DAK Fisik dan Non Fisik (PMK No.50/PMK.70 /2017). Dimensi dari Dana Alokasi Khusus dalam penelitian ini adalah DAK Fisik dan DAK Non Fisik.

\section{Pendapatan Per Kapita (Z)}

Pendapatan per kapita dengan proxy PDB/PDRB per kapita adalah nilai PDB atau PDRB dibagi jumlah penduduk dalam suatu wilayah per periode tertentu (www. sirusa.bps.go.id). Dimensi dari pendapatan per kapita dalam penelitian ini adalah PDB/PDRB dan jumlah penduduk.

Populasi dan Sampel. Populasi dalam penelitian ini adalah seluruh kabupaten dan kota pada Pemerintah Provinsi Jawa Tengah yang terdiri dari 29 kabupaten dan 6 kota periode tahun 2013-2017. Sampel yang digunakan adalah sebanyak 29 kabupaten dan 6 kota di Provinsi Jawa Tengah periode tahun 2013-2017.

Teknik Pengambilan Sampel. Dalam penelitian ini teknik pengambilan sampel yang diambil yaitu teknik sampling total. Sampling total (Sampel Jenuh) adalah teknik penentuan sampel bila semua anggota populasi digunakan sebagai sampel (Sugiyono, 2016).
Jenis Data. Jenis data yang digunakan dalam penelitian ini adalah data dokumenter. Data dokumenter adalah jenis data penelitian yang antara lain berupa: faktur, jurnal, surat-surat, notulen hasil rapat, memo, atau dalam bentuk laporan program (Indriantoro \& Supomo, 2002).

Sumber Data. Dalam penelitian ini menggunakan sumber data berupa data sekunder. Sumber data dalam penelitian ini menggunakan data sekunder berupa laporan realisasi anggaran tahunan yang dipublikasikan pada website Direktorat Jenderal Perimbangan Keuangan (DJPK) Tahun 20132017 dan data pendapatan per kapita (PDRB Per Kapita atas Harga Berlaku) dari website Badan Pusat Statistik Provinsi Jawa Tengah Tahun 2013-2017 serta data-data dari buku literature dan jurnal yang berhu-bungan dengan penelitian ini

Teknik Pengumpulan Data. Teknik pengumpulan data yang digunakan dalam penelitian ini adalah studi pustaka yang dilakukan dengan membaca literatur sesuai penelitian ini sehingga dapat diperoleh data dan landasan teori yang relevan dan dokumentasi berupa data tertulis dari laporan realisasi anggaran tahunan yang telah dipublish pada website Direktorat Jenderal Perimbangan Keuangan (DJPK) dan data Pendapatan per Kapita (PDRB Per Kapita atas Harga Berlaku) dari website Badan Pusat Statistik selama 5 tahun secara berturut-turut dari tahun 2013 hingga tahun 2017.

Teknik Analisis Data. Dalam penelitian ini, peneliti menggunakan teknik analisis regresi linier berganda dan Moderated Regression Analysis (MRA).

\section{HASIL DAN PEMBAHASAN}

\section{Hasil Analisis Regresi Linier Bergan-} da. Hasil analisis regresi linier berganda dapat dilihat pada tabel 2. Dari tabel tersebut 
dapat dirumuskan persamaan regresi sebagai berikut:

$Y=-5095806256153+199932414910,1 . X_{1}$ $+0,149 \cdot X_{2}+0,238 \cdot X_{3}$

Hasil Analisis Regresi Moderasi (Moderated Regression Analysis). Setelah dilakukan analisis regresi linier berganda, tahapan selanjutnya adalah melakukan analisis regresi moderasi, untuk mengetahui dampak moderating variabel terhadap hubungan antara variabel $\mathrm{X}$ dan $\mathrm{Y}$.

Tabel 2

Hasil Uji Analisis Regresi Linier Berganda

Coefficients $^{a}$

\begin{tabular}{|c|c|c|c|c|c|c|}
\hline \multirow{2}{*}{\multicolumn{2}{|c|}{ Model }} & \multicolumn{2}{|c|}{ Unstandardized Coefficients } & \multirow{2}{*}{$\begin{array}{c}\text { Standardized } \\
\text { Coefficients } \\
\text { Beta } \\
\end{array}$} & \multirow[b]{2}{*}{$t$} & \multirow[b]{2}{*}{ Sig. } \\
\hline & & $\mathrm{B}$ & Std. Error & & & \\
\hline \multirow[t]{4}{*}{1} & (Constant) & -5095806256153 & 535976462766 & & -9.508 & .000 \\
\hline & LnPAD_X1 & 199932414910.1 & 21089009796.2 & .553 & 9.480 & .000 \\
\hline & $\mathrm{DAU}(\mathrm{X} 2)$ & .149 & .044 & .205 & 3.418 & .001 \\
\hline & $\operatorname{DAK}(\times 3)$ & .238 & .084 & .166 & 2.848 & .005 \\
\hline
\end{tabular}

a. Dependent Variable: BELANJA MODAL ( $)$

Sumber : Output IBM SPSS Statistics 21, data sekunder yang diolah, 2020

\section{Tabel 3}

\section{Hasil Uji Analisis Regresi Moderasi dengan MRA}

\begin{tabular}{|c|c|c|c|c|c|}
\hline \multicolumn{6}{|c|}{ Coefficients $^{a}$} \\
\hline \multirow[b]{2}{*}{ Model } & \multicolumn{2}{|c|}{ Unstandardized Coefficients } & \multirow{2}{*}{$\begin{array}{c}\text { Standardized } \\
\text { Coefficients }\end{array}$} & \multirow[b]{2}{*}{$t$} & \multirow[b]{2}{*}{ Sig. } \\
\hline & $\mathrm{B}$ & Std. Error & & & \\
\hline $1 \quad$ (Constant) & -478280630948 & 732122462264 & & -.653 & .514 \\
\hline LnPAD_X1 & 19363310063.1 & 29302346015 & .054 & .661 & .510 \\
\hline $\mathrm{DAU}(\mathrm{X} 2)$ & .199 & .087 & .273 & 2.289 & .023 \\
\hline DAK (X3) & .406 & .139 & .282 & 2.915 & .004 \\
\hline PENDAPATAN PER KAPITA (Z) & -562.629 & 1662.664 & -.064 & -.338 & .735 \\
\hline Moderating_X1.Z & $5.021 \mathrm{E}-009$ & .000 & .540 & 5.982 & .000 \\
\hline Moderating_X2.Z & $3.865 \mathrm{E}-010$ & .000 & .042 & .174 & .862 \\
\hline Moderating_X3.Z & $9.005 \mathrm{E}-010$ & .000 & .027 & .249 & .803 \\
\hline
\end{tabular}

a. Dependent Variable: BELANJA MODAL $M$

Sumber : Output IBM SPSS Statistics 21, data sekunder yang diolah, 2020

Dari tabel 3 menunjukkan hasil persamaan regresi moderasi sebagai berikut :

$$
\begin{aligned}
\mathrm{Y}= & -478280630948+19363310063,1 \mathrm{X}_{1} \\
& +0,199 \mathrm{X}_{2}+0,406 \mathrm{X}_{3}-562,629 \mathrm{Z}+ \\
& 5,021 \mathrm{E}-009 \mathrm{X}_{1} * \mathrm{Z}+3,865 \mathrm{E}-010 \mathrm{X}_{2} * \mathrm{Z} \\
& +9,005 \mathrm{E}-010 \mathrm{X}_{3} * \mathrm{Z}
\end{aligned}
$$

Uji Hipotesis. Berdasarkan kedua persamaan regresi di atas, maka dapat dilakukan uji hipotesis sebagai berikut:

\section{Uji t untuk koefisien $\beta_{1}$ (PAD)}

Berdasarkan hasil perhitungan, dimana $\mathrm{t}$ tabel $=1,97393 ; \mathrm{t}$ hitung $=9,480$ dan signifikan $0,000<\alpha(0,05)$. Karena $t$ hitung > dari t tabel, maka $\mathrm{H}_{\mathrm{A}}$ diterima dan $\mathrm{H}_{0}$ ditolak. Maka ada pengaruh positif signifikan antara $\mathrm{PAD}\left(\mathrm{X}_{1}\right)$ terhadap belanja modal (Y) pada Kabupaten/Kota di Jawa Tengah Tahun 2013-2017.

\section{Uji t untuk koefisien $\boldsymbol{\beta}_{\mathbf{2}}$ (DAU)}

Berdasarkan hasil perhitungan, dimana $\mathrm{t}$ tabel $=1,97393 ; \mathrm{t}$ hitung $=3,418$ dan signifikan $0,001<\alpha(0,05)$. Karena $\mathrm{t}$ hitung > dari t tabel, maka HA diterima 
dan H0 ditolak. Maka ada pengaruh positif signifikan antara DAU $\left(\mathrm{X}_{2}\right)$ terhadap belanja modal (Y) pada Kabupaten/Kota di Jawa Tengah Tahun 2013-2017.

\section{Uji t untuk koefisien $\beta_{3}$ (DAK)}

Berdasarkan hasil perhitungan, dimana $\mathrm{t}$ tabel $=1,97393 ; \mathrm{t}$ hitung $=2,848$ dan signifikan $0,005<\alpha(0,05)$. Karena $\mathrm{t}$ hitung > dari t tabel, maka HA diterima dan H0 ditolak. Maka ada pengaruh positif signifikan antara DAK $\left(\mathrm{X}_{3}\right)$ terhadap belanja modal (Y) pada Kabupaten/Kota di Jawa Tengah Tahun 2013-2017.

4. Uji t untuk interaksi antara Pendapatan Per Kapita dengan PAD

Berdasarkan hasil perhitungan, dimana $\mathrm{t}$ tabel $=-1,97393 ; \mathrm{t}$ hitung $=5,982$ dan signifikansi $0,000<0,05$. Karena thitung $>$ dari t tabel dan nilai signifikasi < dari 0.05, maka H0 ditolak. Maka Pendapatan per Kapita mempengaruhi hubungan antara PAD dan belanja modal pada Pemerintahan Kabupaten dan Kota di Jawa Tengah Periode Tahun 2013-2017.

5. Uji t untuk interaksi antara Pendapatan Per Kapita dengan DAU

Berdasarkan hasil perhitungan, dimana $\mathrm{t}$ tabel $=1,97393 ; \mathrm{t}$ hitung $=0,174$ dan signifikansi 0,862>0,05. Karena thitung
$<$ dari t tabel dan nilai signifikasi > dari 0.05, maka H0 diterima. Maka pendapatan per kapita tidak mempengaruhi hubungan antara DAU dan belanja modal pada Pemerintahan Kabupaten dan Kota di Jawa Tengah Periode Tahun 20132017.

6. Uji t untuk interaksi antara Pendapatan Per Kapita dengan DAK

Berdasarkan hasil perhitungan, dimana $\mathrm{t}$ tabel $=1,97393 ; \mathrm{t}$ hitung $=0,249$ dan signifikansi 0,803>0,05. Karena t hitung $<$ dari t tabel dan nilai signifikasi > dari 0.05, maka H0 diterima. Maka pendapatan per kapita tidak mempengaruhi hubungan antara DAK dan Belanja Modal pada Pemerintahan Kabupaten dan Kota di Jawa Tengah Periode Tahun 2013-2017.

Uji Koefisien Determinasi Persamaan Regresi Berganda. uji koefisien determinasi menunjukkan kemampuan kombinasi variabel $\mathrm{X}$ dalam menjelaskan variabel $\mathrm{Y}$. Berdasarkan tabel 4 besarnya koefisien adjusted $\mathrm{R}^{2}$ sebesar 0,622 ; hal ini menunjukkan bahwa variabel bebas (PAD, DAU, DAK) mampu menjelaskan variabel terikat (Belanja Modal) sebesar 62,2\% dan sisanya $37,8 \%$ dipengaruhi variabel lain yang tidak termasuk didalam model penelitian ini.

Tabel 4

Hasil Uji Koefisien Determinasi Persamaan Reegresi Berganda

Model Summary

\begin{tabular}{|l|l|r|r|r|}
\hline Model & R & R Square & $\begin{array}{c}\text { Adjusted R } \\
\text { Square }\end{array}$ & $\begin{array}{c}\text { Std. Error of } \\
\text { the Estimate }\end{array}$ \\
\hline 1 & $.793^{\mathrm{a}}$ & .629 & .622 & $1.077 \mathrm{E}+11$ \\
\hline
\end{tabular}

a. Predictors: (Constant), DAK (X3), LnPAD_X1, DAU $(X 2)$

Sumber : Output IBM SPSS Statistics 21, data sekunder yang diolah, 2020

Uji Koefisien Determinasi Persamaan Regresi Moderasi. Seperti halnya dalam persamaan regresi berganda, pada persama- an regresi moderasi juga dilakukan uji koefisien determinasi untuk melihat model mana yang lebih baik. Berdasarkan tabel 5 
besarnya koefisien adjusted $\mathrm{R}^{2}$ sebesar 0.737, hal ini menunjukkan bahwa gabungan variabel bebas (PAD, DAU, DAK, Pendapatan Per Kapita, Moderating_X1.Z, Moderating_X2.Z, Moderating_X3.Z) mampu menjelaskan variabel terikat
(Belanja Modal) sebesar 73,7\% dan sisanya $26,3 \%$ dipengaruhi variabel lain yang tidak termasuk didalam model penelitian ini. Hal ini menunjukkan bahwa persamaan model regresi moderasi merupakan model yang lebih baik daripada regresi berganda.

Tabel 5

Hasil Uji Koefisien Determinasi Persamaan Regresi Moderasi Model Summary

\begin{tabular}{|l|l|r|r|c|}
\hline Model & R & R Square & $\begin{array}{c}\text { Adjusted R } \\
\text { Square }\end{array}$ & $\begin{array}{c}\text { Std. Error of } \\
\text { the Estimate }\end{array}$ \\
\hline 1 & $.865^{\mathrm{a}}$ & .748 & .737 & 89817951635 \\
\hline
\end{tabular}

a. Predictors: (Constant), Moderating_X3.Z, DAU $(X 2)$, Moderating_X1.Z, PENDAPATAN PER KAPITA (Z),

LnPAD_X1, DAK (X3), Moderating_X2.Z

Sumber : Output IBM SPSS Statistics 21, data sekunder yang diolah, 2020

Pembahasan. Pembahasan atas hasil penelitian yang telah dijabarkan di atas adalah sebagai berikut:

\section{Pendapatan Asli Daerah $\left(\mathrm{X}_{1}\right)$ Terha- dap Belanja Modal (Y)}

Berdasarkan hasil uji hipotesis dapat diketahui bahwa ada pengaruh positif signifikan antara Pendapatan Asli Daerah $\left(\mathrm{X}_{1}\right)$ terhadap belanja modal (Y) Kabupaten/ Kota di Jawa Tengah Tahun 2013-2017.

Hal ini membuktikan bahwa dalam meningkatkan anggaran belanja pembangunan yang didalamnya terdapat komponen belanja modal maka pemerintah daerah harus mampu meningkatkan pendapatan daerah salah satunya dengan meningkatkan PAD (Badrudin, 2017), Hasil penelitian ini sejalan dengan penelitian yang dilakukan oleh Aditiya \& Dirgantari (2017) dan Sianturi \& Putri (2018) yang menunjukkan bahwa PAD berpengaruh positif signifikan terhadap belanja modal.

\section{Dana Alokasi Umum $\left(\mathrm{X}_{2}\right)$ Terhadap Belanja Modal (Y)}

Berdasarkan hasil uji hipotesis diketahui bahwa ada ada pengaruh positif signifikan antara DAU $\left(\mathrm{X}_{2}\right)$ terhadap belanja modal
(Y) Kabupaten/Kota di Jawa Tengah Tahun 2013-2017.

Hal ini membuktikan bahwa untuk meningkatkan belanja modal, pemerintah daerah harus mampu meningkatkan pendapatan daerah salah satunya melalui dana perimbangan yang didalamnya terdapat DAU (Badrudin, 2017). DAU bertujuan untuk pemerataan kemampuan keuangan antardaerah dengan penerapan formula yang mempertimbangkan kebutuhan dan potensi daerah. Alokasi DAU bagi daerah yang potensi fiskalnya besar tetapi kebutuhan fiskal kecil akan memperolah alokasi DAU relatif kecil (Badrudin, 2017).

Hasil penelitian ini sejalan dengan penelitian yang dilakukan oleh Kosim (2017) dan Sianturi dan Putri (2018) bahwa Dana Alokasi Umum berpengaruh terhadap belanja modal.

\section{Dana Alokasi Khusus $\left(\mathrm{X}_{3}\right)$ Terhadap} Belanja Modal (Y)

Berdasarkan hasil uji hipotesis diketahui bahwa ada pengaruh positif signifikan antara DAK (X3) terhadap Belanja Modal (Y) Kabupaten/Kota di Jawa Tengah Tahun 2013-2017. 
Hal ini membuktikan bahwa untuk meningkatkan belanja modal, pemerintah daerah harus mampu meningkatkan pendapatan daerah salah satunya melalui dana perimbangan yang didalamnya terdapat DAK (Badrudin, 2017), dimana DAK dialokasikan kepada daerah tertentu untuk mendanai khusus yang merupakan urusan daerah salah satu contohnya adanya DAK fisik berupa infrastruktur publik daerah.

Hasil penelitian ini sejalan dengan penelitian yang dilakukan oleh Sari \& Wirama (2018) dan Sianturi \& Putri (2018) yang menunjukkan bahwa DAK berpengaruh positif terhadap belanja modal.

\section{Pendapatan Per Kapita (Z) sebagai}

Pemoderasi Pendapatan Asli Daerah $\left(\mathrm{X}_{1}\right)$ terhadap Belanja Modal (Y)

Berdasarkan hasil uji hipotesis dapat diketahui bahwa bahwa pendapatan per kapita sebagai variabel moderating mampu mempengaruhi hubungan PAD terhadap belanja modal pada pemerintahan kabupaten dan kota di Jawa Tengah periode Tahun 2013-2017.

Hal ini membuktikan bahwa pendapatan per kapita sebagai variabel pemoderasi mampu memperkuat belanja modal dengan memperhatikan indikator pada Pendapatan Asli Daerah yang terdiri dari pajak daerah, retribusi daerah, hasil pengelolaan kekayaan daerah yang dipisahkan, dan lain-lain pendapatan asli daerah yang sah (UU Nomor 33 Tahun 2004) dengan indikator pendapatan per kapita berupa nilai PDB atau PDRB dan jumlah penduduk dalam suatu wilayah (www.sirusa.bps.go.id). Pendapatan perkapita tidak secara langsung mempengaruhi Pendapatan Asli Daerah karena partumbuhan pendapatan per kapita yang dari tahun ke tahun akan meningkatkan taraf kesejahteraan dan kemampuan masyarakat untuk memenuhi kebutuhannya sehingga akan membelanjakan pendapatan yang diterima di sektor-sektor ekonomi, dan peningkatan aktivitas perekonomian tersebut akan memberikan sumbangan kepada beberapa sumber Pendapatan Asli Daerah dalam bentuk setoran pajak dan retribusi yang akan digunakan daerah untuk membiayai pembangunan dan melaksanakan pelayanan kepada masyarakat (Dengah dkk, 2014).

Hasil penelitian ini sejalan dengan penelitian sebelumnya yang dilakukan oleh Fahrunisah dan Badjuri (2017) menggunakan pertumbuhan ekonomi sebagai variabel pemoderasi yang diukur dengan Produk Domestik Bruto Per Kapita (Pendapatan Per Kapita) menyatakan bahwa Pertumbuhan Ekonomi mampu memperkuat hubungan antara Pendapatan Asli Daerah terhadap Belanja Modal.

\section{Pendapatan Per Kapita (Z) Sebagai} Pemoderasi Dana Alokasi Umum $\left(\mathbf{X}_{2}\right)$ Terhadap Belanja Modal (Y)

Berdasarkan hasil uji hipotesis dapat diketahui bahwa pendapatan per kapita sebagai variabel moderating tidak mampu mempengaruhi hubungan DAU terhadap belanja modal pada Pemerintahan Kabupaten dan Kota di Jawa Tengah Periode Tahun 2013-2017.

Penelitian ini tidak dapat membuktikan bahwa pertumbuhan pendapatan per kapita akan mempengaruhi hubungan DAU yang berasal dari dana APBN pemerintah pusat terhadap pengalokasian belanja modal. Sesuai hakikat teori kontijensi adalah tidak ada satu cara terbaik yang bisa digunakan dalam semua keadaan (situasi) lingkungan (Mulyani dan Wibowo, 2017). Dalam hal ini dengan adanya variabel moderasi pendapatan per kapita yang diukur dengan PDRB per kapita sebagai faktor kontinjensi dimana merupakan salah satu faktor pengukur alokasi DAU atas dasar celah fiskal dalam kebutuhan fiskal belum dapat memberikan pengaruh kuat antara Dana Alokasi Umum 
terhadap belanja modal, akan tetapi DAU sendiri dapat mempengaruhi alokasi belanja modal tanpa adanya variabel moderasi.

Hasil penelitian ini sejalan dengan penelitian sebelumnya yang dilakukan oleh Sari dan Wirama (2018) menyatakan bahwa Pendapatan Per Kapita tidak memoderasi DAU pada Alokasi Belanja Modal.

\section{Pendapatan Per Kapita (Z) Sebagai} Pemoderasi Dana Alokasi Khusus $\left(\mathbf{X}_{3}\right)$ Terhadap Belanja Modal (Y)

Berdasarkan hasil uji hipotesis dapat diketahui bahwa bahwa pendapatan per kapita sebagai variabel moderating tidak mampu mempengaruhi hubungan DAK terhadap belanja modal pada Pemerintahan Kabupaten dan Kota di Jawa Tengah Periode Tahun 2013-2017.

Penelitian ini tidak dapat membuktikan bahwa pertumbuhan pendapatan per kapita mempengaruhi hubungan DAK yang berasal dari dana APBN pemerintah pusat terhadap pengalokasian belanja modal. Berkaitan dengan pendekatan kontinjensi untuk mengidentifikasi variabel kontinjensi yang mempengaruhi perancangan dalam hal ini faktor kontijensi yang digunakan adalah pendapatan per kapita, maka hubungan DAK dengan pengalokasian belanja modal belum dapat diperkuat oleh pendapatan per kapita yang diukur dengan PDRB per kapita pada tiap daerah dikarenakan alokasi DAK sendiri tidak hanya ditetapkan berdasarkan kriteria umum seperti kemampuan keuangan daerah melainkan juga ditetapkan berdasarkan kriteria khusus dan kriteria teknis, akan tetapi Dana Alokasi Khusus sendiri dapat memberi pengaruh positif terhadap alokasi belanja modal tanpa disertai dengan variabel pemoderasi.

Hasil penelitian ini sejalan dengan penelitian sebelumnya yang dilakukan oleh Sari dan Wirama (2018) menyatakan bahwa pendapatan per kapita tidak memoderasi DAK pada Alokasi Belanja Modal.

\section{PENUTUP}

Kesimpulan. Berdasarkan hasil penelitian dan pembahasan di bab sebelumnya, maka dapat ditarik kesimpulan sebagai berikut:

1. PAD (X1) berpengaruh positif signifikan terhadap belanja modal (Y) pada Pemerintahan Kabupaten/Kota di Jawa Tengah Tahun 2013 - 2017.

2. DAU (X2) berpengaruh positif signifikan terhadap belanja modal (Y) pada Pemerintahan Kabupaten/Kota di Jawa Tengah Tahun 2013 - 2017.

3. DAK (X3) berpengaruh positif signifikan terhadap belanja modal (Y) pada Pemerintahan Kabupaten/Kota di Jawa Tengah Tahun 2013 - 2017.

4. Pendapatan per kapita (Z) mampu mempengaruhi hubungan PAD (X1) terhadap belanja modal (Y) pada Pemerintahan Kabupaten/Kota di Jawa Tengah Periode Tahun 2013-2017.

5. Pendapatan per kapita $(Z)$ tidak mampu mempengaruhi hubungan DAU (X2) terhadap belanja modal (Y) pada Pemerintahan Kabupaten/Kota di Jawa Tengah Periode Tahun 2013-2017.

6. Pendapatan per kapita (Z) tidak mampu mempengaruhi hubungan DAK (X3) terhadap belanja modal (Y) pada Pemerintahan Kabupaten/Kota di Jawa Tengah Periode Tahun 2013-2017.

Saran. Berdasarkan kesimpulan tersebut, maka saran yang dapat diajukan berdasarkan penelitian ini antara lain:

1. Saran bagi Pemerintah Daerah yaitu dalam meningkatkan pengalokasian belanja modal diharapkan pemerintah daerah dapat mengoptimalkan potensi dan kewenangan daerah yang dimiliki 
untuk meningkatkan pendapatan asli daerah, dana alokasi umum, dan dana alokasi khusus dimana berdasarkan penelitian ini diketahui bahwa PAD, DAU, dan DAK memiliki pengaruh positif signifikan terhadap belanja modal dan dengan pendapatan per kapita dapat memperkuat pengaruh hubungan PAD terhadap belanja modal, maka melalui otonomi daerah dan desentralisasi fiskal, pemerintah memiliki wewenang untuk menggali pendapatan dan melakukan peran alokasi secara mandiri dalam menetapkan prioritas pembangunan, serta Pemerintah daerah diharapkan dapat menetapkan anggaran belanja pembangunan yang didalamnya ada komponen belanja modal lebih besar daripada anggaran pengeluaran rutin.

2. Saran bagi penelitian selanjutnya yaitu penelitian dapat dilakukan pada kabupaten/kota yang lainnya diseluruh provinsi yang ada di Indonesia sehingga hasil penelitiannya lebih representative terhadap populasi yang dipilih dan penelitian yang akan datang dapat menguji variabel independen lainnya yang lebih lengkap dan bervariasi dimana variabel tersebut diduga berpengaruh terhadap alokasi belanja modal seperti DBH, SiLPA, dan juga dapat menambahkan rasio keuangan lainnya yang diperkirakan dapat mempengaruhi belanja modal.

\section{DAFTAR PUSTAKA}

Adyatama, Erdi., \& Oktaviani, Rachmawati Meita. 2015. Pengaruh Pendapatan Asli Daerah Dan Dana Alokasi Umum Terhadap Belanja Modal Dengan Pertumbuhan Ekonomi Sebagai Pemoderasi. Dinamika Akuntansi, Keuangan dan Perbankan, 4(2), 190-205. https://www.unisbank.ac.id/ojs/index.php/ fe9/article/view/4598

Aditiya, Nanda Yoga., \& Dirgantari, Novi. 2017. Pengaruh Pendapatam Asli Daerah (PAD), Dana Alokasi Umum (DAU), Dana Alokasi Khusus (DAK) Dan Sisa Lebih Pembiayaan Anggaran (SILPA) Terhadap Belanja Modal Pada Kabupaten Dan Kota Di Jawa Tengah Tahun 2013 2015. Kompartemen : Jurnal Ilmiah Akuntansi, $\quad \mathrm{XV}(1), \quad 42-56$. http://jurnalnasional.ump.ac.id/index.php/ kompartemen/article/view/1378

Badrudin, Rudy. 2017. Ekonomika Otonomi Daerah (edisi kedua). Yogyakarta : UPP STIM YKPN

Badan Pusat Statistik Provinsi Jawa Tengah. Publication. (Online) (https://www.bps.go.id/publication/2018/1 0/05/89552064fb46e82d2b50468f/produk -domestik-regional-bruto-kabupaten-kotadi-indonesia-2013-2017.html, diakses 22 Oktober 2019).

Bastian, Indra. 2006. Akuntansi Sektor Publik Suatu Pengantar. Jakarta : Erlangga.

Bisnis.com. 2019. Sri Mulyani : Hanya 30 Persen dari APBD yang Berdampak kepada Rakyat. (Online) (https://ekonomi.bisnis.com/read/2019111 4/10 /1170404/sri-mulyani-hanya-30persen-dari-apbd-yang-berdampakkepada-rakyat, diakses 01 Mei 2020)

Cahyaning, Sri. 2018. Pengaruh Pendapatan Asli Daerah, Dana Alokasi Umum Dan Dana Bagi Hasil Terhadap Alokasi Belanja Modal Dengan Pertumbuhan Ekonomi Sebagai Variabel Moderating Pada Pemerintah Daerah Kabupaten/Kota Provinsi Jawa Timur Tahun 2013-2015. Jurnal Ilmu Ekonomi Terapan (JIET). Vol 3, No 1, 1-38. https://ejournal.unair.ac.id/JIET/article/view/7874

Detiknews. 2019. Desentralisasi dan Ketergantungan Fiskal Daerah. (Online) (https://news.detik.com/kolom/d4406834/desentralisasi-danketergantungan-fiskal-daerah, diakses 03 Mei 2019) 
Dengah, dkk. 2014. Analisis Pengaruh Pendapatan Perkapita Dan Jumlah Penduduk Terhadap Permintaan Perumahan Kota Manado Tahun 20032012. Jurnal Berkala Ilmiah Efisiensi. Volume 14, Nomor 3, 71-81. https://ejournal.unsrat.ac.id/index.php/jbie /article/view/5463

DJPK - Kementrian Keuangan Republik Indonesia. Visualisasi Data APBD - Tabel Agregat.

(Online) (http://www.djpk.kemenkeu.go.id/visual/\# /tabel2, diakses 03 Mei 2019).

Fahrunisah, Noora \& Badjuri, Achmad. 2017. Faktor-Faktor Yang Mempengaruhi Belanja Modal Dengan Pertumbuhan Ekonomi Sebagai Variabel Pemoderasi. Dinamika Akuntansi, Keuangan dan Perbankan. Vol. 6, No. 2

Ghozali, Imam. 2011. Aplikasi Analisis Mulivariate Dengan Program ABM SPSS 19. Semarang : Universitas Diponegoro.

Harianto, David., \& Adi, Priyo Hari. 2015. Hubungan Antara Dana Alokasi Umum, Belanja Modal, Pendapatan Asli Daerah Dan Pendapatan Per Kapita. Simposium Nasional Akuntansi X Unhas Makassar 26-28 Juli 2007, ASPP-15, 1-26. https://www.researchgate.net/publication/ 265074280_HUBUNGAN_ANTARA_D ANA_ALOKASI_UMUM_BELANJA MODAL PENDAPATAN ASLI DAER AH DAN PENDAPATAN PER KAPI $\underline{\mathrm{TA}}$

Hudayati, Ataina. 2002. Perkembangan Penelitian Akuntansi Keperilakuan: Berbagai Teori Dan Pendekatan Yang Melandasi. JAAI, Volume 6, Nomor 2, 81-96.

https://media.neliti.com/media/publication s/74568-none-93226d40.pdf

Indriantoro, Nur., \& Supomo, Bambang. 2002. Metodologi Penelitian Bisnis Untuk Akuntansi \& Manajemen (edisi pertama). Yogyakarta : BPFE Yogyakarta.

Jaeni \& Anggana L, Greg. 2016. Pertumbuhan Ekonomi Sebagai Variabel Pemoderasi Pendapatan Asli Daerah Dan Bantuan
Propinsi Terhadap Belanja Modal. Dinamika Akuntansi, Keuangan dan Perbankan.Vol.5, No.1

Jaya, I Putu Ngurah Panji Kartika \& Dwirandra, A.A.N.B. 2014. Pengaruh Pendapatan Asli Daerah Pada Belanja Modal Dengan Pertumbuhan Ekonomi Sebagai Variabel Pemoderasi. E-Jurnal Akuntansi Universitas Udayana, 7.1 (2014):79-92. https://ojs.unud.ac.id/index.php/Akuntansi /article/view/8643

Kosim, Engkos. 2017. Pengaruh Pendapatan Asli Daerah (PAD), Dana Alokasi Umum (DAU) Dan Sisa Lebih Pembiayaan Anggaran (SILPA) Terhadap Anggaran Belanja Modal Pada Pemerintah Kota Banjar. Journal of Management Review, Volume 1, Number 1, 13-23. http://jurnal.unigal.ac.id/index.php/manag ementreview

Mulyani, Sri \& Wibowo Hardiyanto. 2017. Pengaruh Belanja Modal, Ukuran PemerintahDaerah,

Intergovernmentalrevenue Dan Pendapatan Asli Daerah Terhadap Kinerja Keuangan. KOMPARTEMEN, Vol. XV No.1, 57-66. http://jurnalnasional.ump.ac.id/index.php/ kompartemen/article/view/1379

Mohklas \& Devi Inanta Purwati. 2019. Memoderasikah Pertumbuhan Ekonomi Terhadap Belanja Modal? (Studi Kasus Pada Pemerintah Kabupaten/Kota di Provinsi Jawa Tengah Periode 20122016). Journal of Management and Business, Vol 2, No 1, 1-19. http://journal.upgris.ac.id/index.php/stabil ity/article/view/4029/2559

Sari, D.M.M.Y., \& Wirama, D.G. 2018. Pengaruh PAD, DAU, dan DAK Pada Alokasi Belanja Modal dengan Pendapatan Per Kapita Sebagai Pemoderasi. E-Jurnal Akuntansi Universitas Udayana, 22(3), 2065-2087. https://ojs.unud.ac.id/index.php/Akuntansi /article/view/36964

Sianturi dan Putri. 2018. Pengaruh Pendapatan Asli Daerah, Dana Alokasi Umum, Dan 
Dana Alokasi Khusus Terhadap Pengalokasian Anggaran Belanja Modal. Jurnal Ilmiah Akuntansi dan Ekonomi, Volume .1, No. 3. 1-19. https://www.lppm.usni.ac.id/jurnal/1.\%20 P\%20HERISTON\%20(\%201-19\%20).pdf

Sirusa Badan Pusat Statistik. PDB/PDRB Per Kapita.

(Online) (https://sirusa.bps.go.id/sirusa/index.php/i ndikator/74, diakses 28-12-2019)

Sugiarthi, N.P.D.E.R., \& Supadmi, N.L. 2014. Pengaruh Pad, Dau, Dan Silpa Pada Belanja Modal Dengan Pertumbuhan Ekonomi Sebagai Pemoderasi. E-Jurnal Akuntansi Universitas Udayana, 7.2, 477495.

https://ojs.unud.ac.id/index.php/Akuntansi /article/view/8944

Sugiyono. 2016. Statistika Untuk Penelitian. Bandung : CV Alfabeta

Wandira, Arbie Gugus. 2013. Pengaruh PAD, DAU, DAK, Dan DBH Terhadap
Pengalokasian Belanja Modal. Accounting Analysis Journal, 2(1), 45-51. https://journal.unnes.ac.id/sju/index.php/a aj/article/view/1158

Wibisono dan Wildaniati. 2016. Pengaruh Pertumbuhan Ekonomi, PAD, DAU, SiLPA Dan Luas Wilayah Terhadap Alokasi Anggaran Belanja Modal. Jurnal Ilmu Ekonomi, Manajemen, dan Akutansi, Volume 5, Nomor2, ISSN:230-4747. http://www.unmermadiun.ac.id/ejurnal/in dex.php/ekomaks/article/view/212/412 . Peraturan Pemerintah Nomor 71 Tahun 2010 Tentang Standar Akuntansi Pemerintah.

. Undang-Undang Republik Indonesia Nomor 33 Tahun 2004 Tentang Perimbangan Keuangan Antara Pemerintah Pusat dan Pemerintah Daerah. Peraturan Menteri Keuangan Nomor 50/PMK.70/2017 tentang Pengelolaan Transfer ke Daerah dan Dana Desa. 